\title{
Geociências
}

\section{Mineralogy and chemistry of the green stone artifacts (muiraquitãs) of the museums of the Brazilian State of Pará}

\author{
Mineralogia e química de artefatos de \\ pedra verde (muiraquitãs) dos Museus \\ do Estado do Pará
}

Anna Cristina Resque Meirelles

Doctoral student,

PPGG - Instituto de Geociências,

Universidade Federal do Pará.

annaresque@hotmail.com

Marcondes Lima da Costa

Professor, Instituto de Geociências,

Universidade Federal do Pará;

CNPq researcher.

mlc@ufpa.br

\section{Resumo}

Os muiraquitãs foram considerados de proveniência asiática ou, também, como peças esculpidas pelas lendárias mulheres guerreiras, as Amazonas. São peças, hoje, muito raras, encontradas em alguns acervos de Museus. Estudos mineralógicos e químicos de 23 peças do acervo dos Museus de Gemas e do Encontro em Belém, Brasil, mostraram que os muiraquitãs podem ser constituídos, tanto de quartzo, como de albita, ou microclínio, pirofilita, variscita, anortita e tremolita (equivalente ao jade nefrítico), minerais frequentes em formações geológicas do Brasil. No entanto quatro peças são constituídas de jadeíta, ou seja, em jade jadeítico, raro e desconhecido na Amazônia e Brasil. A constatação da presença desse mineral reacende a discussão em torno da origem mineralógica dos muiraquitãs encontrados na Amazônia. Essa origem, antes da atual descoberta, era defendida como amazônica, devido à ausência de jade jadeítico nas peças pesquisadas e pelo fato de jadeíta não ter sido encontrada no Brasil, mas na América Central e na Ásia.

Palavras-chave: Muiraquitã, jade, jadeíta, Amazônia, tremolita, actinolita.

\section{Abstract}

Muiraquitãs, lithic artifacts found in the Amazon basin, have been considered to be Asian in origin, or to have been sculpted by the legendary female Amazon warriors. These pieces are now very rare, and are found mainly in museum collections. In the present study, the mineralogical and chemical content of 23 specimens from the collections of the Museu de Gemas (Gemstone Museum) and Museu do Encontro (Meeting Museum) in Belém, Brazil, were analyzed. Most of the pieces were made of minerals commonly found in Brazil - quartz, albite, microcline, variscite, anorthite, and tremolite (the equivalent of nephritic jade). However, four of the pieces were made of jadeite, that is, jadeitic jade, which is unknown in the Amazon basin or in other parts of Brazil. The confirmation of the presence of this mineral in some of the artifacts reopens the debate on the mineralogical origin of the muiraquitãs found in the Amazon basin. Before the present discovery, their origin was defended as Amazonian due to the absence of jadeite jade in the searched pieces and the fact that jadeite was not found in Brazil but in Central America and Asia.

Keywords: Muiraquitã, jade, jadeite, Amazonia, tremolite, actinolite. 


\section{Introduction}

The muiraquitãs are lithic artifacts normally sculpted from different kinds of green stones used as amulets and symbols of commerce and power by preColombian peoples that inhabited the lower Amazon basin.

These artifacts are related, in both oral and written traditions, to the legends of the Amazon warriors, the Ikamiabas, described by Carvajal during the Orellana expedition of 1540-1542, when the first European explorers descended the Amazon River. In the present day, the muiraquitãs are rare pieces, found mainly in the collections of museums, such as the Museu Paraense Emílio Goeldi-MPEG (Goeldi Museum), the Museu do Encontro (Meeting Museum) and the Museu de Gemas (Gemstone Museum) in the Brazilian city of Belém, state of Pará, and the Museu de Arqueologia e Etnografia - MAE (Museum of Archeology and Ethnology) of the Universidade de São Paulo - USP (University of São Paulo) in the city of São Paulo. Some pieces are held by private collectors, not only in the Ama-

\section{Material and methods}

The present study focused on 22 muiraquitãs and a bead, which are on display in the Museu de Gemas (Gemstone Museum) and the Museu do Encontro (Meeting Museum). The Gemstone Museum is located in the São José Liberto Cultural Center, and the Museu do Encontro (Meeting Museum) in Presépio Fort.

All the specimens were initially described macroscopically in terms of their form, design, holes, color, dimensions, weight, and degree of conservation, polish, and luster. The next step was the collection of samples for analysis. Given the rarity of the material and the archeological significance of the specimens, the samples were collected from

\section{Results and discussion}

\section{Morphology and mineralogy}

The muiraquitãs analyzed in the present study are shown in Figures 1 (Museu de Gemas) and 2 (Museu do Encontro). All the specimens from the Museu de Gemas are batrachian in form and vary in length from $20 \mathrm{~mm}$ to $135 \mathrm{~mm}$, with colors ranging from green to yellow and brown. All the specimens have a single zon region, but even in other countries, especially in Europe, where the specimens were taken in the past centuries.

Most of the reports and publications on these artifacts (Rodrigues, 1899; Moraes, 1932; Koehler, 1951; Barata, 1954; Boomert, 1987; Silva et al., 1997; Costa et al., 2002a, 2002b) indicate that the muiraquitãs are generally made of nephritic jade, a hard, greenish, microfibrous material normally considered to be a rock, rather than a mineral. Jade may be constituted either of jadeite $\left(\mathrm{NaAlSi}_{2} \mathrm{O}_{6}\right)$ or nephrite, which is normally formed by tremolite or tremolite-actinolite $\mathrm{Ca}_{2}(\mathrm{Mg}, \mathrm{Fe})_{5}\left(\mathrm{Si}_{8} \mathrm{O}_{22}\right)(\mathrm{OH})_{2}$.

As jade is not known to occur in Brazil (considering only jadeite), Rodrigues (1899) suggested that these artifacts, or at least their raw material, would have come from Asia during the migrations of the human populations that originally colonized the New World, passing first through North America to reach South America and the Amazon basin. This hypothesis was nevertheless rejected by a number

the internal surface of one of the holes, with at least $5 \mathrm{mg}$ being extracted from each specimen using an electric microdrill with a diamond bit. A total of 23 micro-aliquots were obtained. In order to avoid the scattering and loss of material, the sample and the tip of the drill bit were immediately immersed in ethanol in a flat-bottomed glass container. This container was heated on a metal plate until all the ethanol evaporated and the residual dust was collected.

For the determination of mineralogical content by X-ray diffraction (XRD), the micro-aliquots were mounted on a quartz sample-holder. A PANalytical X'PERT PRO MPD (PW of subsequent authors (Fischer, 1884; Moraes, 1932; Kohler, 1951; Boomert, 1987). The jade of the muiraquitãs may have been originated in the Amazon basin, given the abundance of rocks rich in tremolite and/or tremolite-actinolite in many of the region's geological domains (Costa et al., 2002a).

The first mineralogical investigation of the muiraquitãs (Costa et al., 2002a) was restricted to the MAE collection and pieces owned by private collectors from the city of Belém. More recently, it has been possible to examine a much larger number of specimens available in the collection held by the Pará State museums providing a much more reliable sampling for the mineralogical analysis of these artifacts, and the discussion of their probable origin and use. The results of these new analyses are presented here and discussed in the context of both the previous studies and the geological, archeological, and ethnographic context of the Amazon region.

3040/60) X-ray diffractometer with a PW3050/60 (theta to theta) goniometer and a PW3373/00 fine long focus, 220W, $60 \mathrm{Kv}$, ceramic $\mathrm{Cu}\left(\mathrm{K} \alpha_{1} 1.540598 \AA\right)$ anode X-ray tube was used for this analysis. An RTMS, X'Celerator-type detector was used. Data were collated using the X'Pert Data Collector (version 2.1b) software, also from PANalytical. The analyses were conducted in the X-ray Laboratory of the Geosciences Institute of the Federal University of Pará. All mineralogical analyses were supported by chemical analysis using a dispersive energy system (EDS) coupled to a scanning electron microscope (SEM) in the Museu Goeldi. transversal or frontal hole, except for number 506, which has double holes not visible from the front. In addition to batrachian forms, Barata (1954) identified the double lateral holes as a reliable criterion for the recognition of a true muiraquitã.

By contrast, the muiraquitãs from the collection of the Museu do Encontro vary in form from batrachian to indeterminate, with colors ranging from light green to bluish green, and length of 21$66 \mathrm{~mm}$. All specimens have a single hole, either frontal or lateral. Overall, then, the set of specimens in the two museums were somewhat different in terms of form, size, and color. 
Figure 1

Muiraquitãs and a bead from the collection of Museu de Gemas (Gemstone Museum) of the Pará State in the city of Belém (Brazil), indicating the principal mineral components, as defined by XRD and SEM/EDS.

The XRD and SEM/EDS analyses showed clearly that the muiraquitãs are made up of a number of different mineral species, varying considerably among the specimens. The main constituents can be one or even two of the following minerals: quartz $\left(\mathrm{SiO}_{2}\right)$, tremolite to tremoliteactinolite $\mathrm{Ca}_{2}(\mathrm{Mg}, \mathrm{Fe})_{5}\left(\mathrm{Si}_{8} \mathrm{O}_{22}\right)(\mathrm{OH})_{2}$, jadeite $\left(\mathrm{NaAlSi}_{2} \mathrm{O}_{6}\right)$, variscite $\left(\mathrm{Al}\left(\mathrm{PO}_{4}\right)\right.$ $2\left(\mathrm{H}_{2} \mathrm{O}\right)$, variscite-strengite $\left(\mathrm{Al}, \mathrm{Fe}^{3+}\right)\left(\mathrm{PO}_{4}\right)$ $2\left(\mathrm{H}_{2} \mathrm{O}\right)$, anorthite $\left(\mathrm{CaAl}_{2} \mathrm{Si}_{2} \mathrm{O}_{8}\right)$, albite $\left(\mathrm{NaAlSi}_{3} \mathrm{O}_{8}\right)$, and microcline $\left(\mathrm{KAlSi}_{3} \mathrm{O}_{8}\right)$.

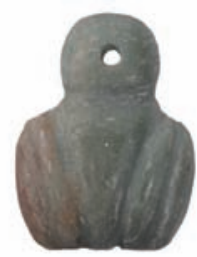

504

quartz

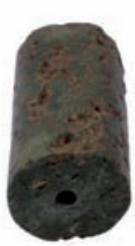

509

veriscite-strengite

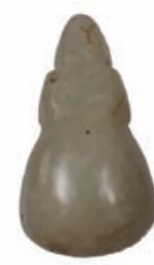

505

tremolite

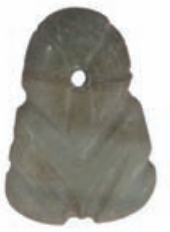

510

quartz

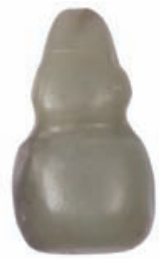

506

tremolite

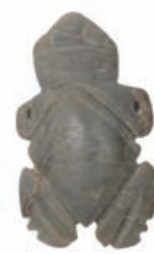

507

anorthite

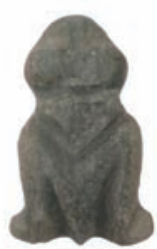

508

quartz
Seven muiraquitãs from these museums (catalog numbers 504, 508, 510, $516,517,526$, and 527) were registered as being made of jadeite, but they were in fact sculpted in quartz, a material distinct from jade. However, in contrast with the analyses of Costa et al. (2002a), which concluded that none of the specimens analyzed from the MAE and Museu Goeldi were made of jadeite, four pieces from the Museu do Encontro (catalog numbers 518, 519, 523, and
524) are made of this material. Another seven pieces (catalog numbers 512-515, 521, 522 and 523) are constituted of albite, plus microcline and quartz, rather than amazonite, as recorded in the collection. One other piece (number 507) catalogued as jadeite is in fact made of anorthite, a plagioclase feldspar. Tremolite-actinolite was identified in three muiraquitãs (numbers 505, 506, and 520), and green variscite-strengite phosphates in specimen 509.
Figure 2

Muiraquitãs from the collection of the Pará State Museu do Encontro (Meeting Museum) in the city of Belém (Brazil), indicating the principal mineral components, as defined by XRD and SEM/EDS.

\section{Chemical composition}

The chemical composition of the muiraquitãs from the Museu de Gemas and Museu de Encontro was determined using SEM/EDS (Table 1). While these results can only be considered to be semi-

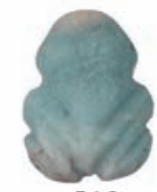

512

albite + microcline

+ quartz

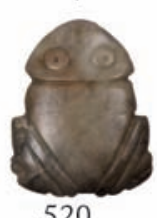

520 tremolite

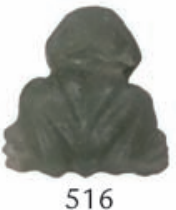

quartz

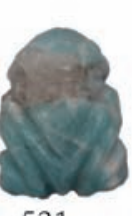

521

+ microcline

+ quartz

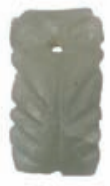

525

jadeite

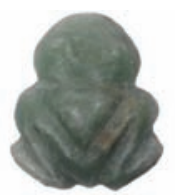

517

quartz

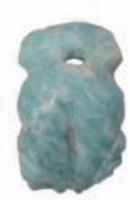

522

albite + microc

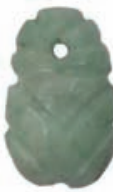

518

jadeite

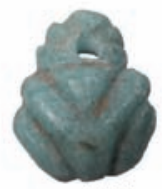

523

+ quartz

+ quartz
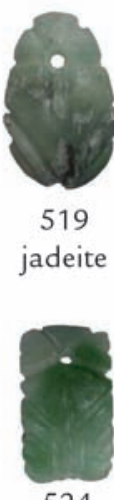

524

jadeite

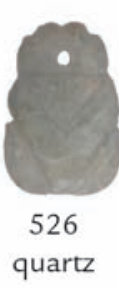

quantitative, they are highly consistent with the composition of the respective minerals.

As expected from their diverse mineralogical composition, the chemical composition of the muiraquitãs varied considerably. The principal components are $\mathrm{SiO}_{2}, \mathrm{Al}_{2} \mathrm{O}_{3}, \mathrm{MgO}, \mathrm{Fe}_{2} \mathrm{O}_{3}, \mathrm{CaO}, \mathrm{K}_{2} \mathrm{O}$, $\mathrm{Na}_{2} \mathrm{O}$, and $\mathrm{P}_{2} \mathrm{O}_{5}$, but with marked variation in values. For example, $\mathrm{SiO}_{2}$ ranges from $47.4 \%$ to $99.9 \%, \mathrm{Al}_{2} \mathrm{O}_{3}$ from $0.7 \%$ 
to $32 \%$, and $\mathrm{MgO}$ from $23.7 \%$ to $25 \%$ (Table 1). Even so, it is possible to identify more homogeneous groups, which correspond to a given mineral domain (Table 1).
The quartz domain (muiraquitãs $504,508,510,516,517,526$, and 527) is easily identified by the predominance of $\mathrm{SiO}_{2}$. The chemical composition of muira-

\begin{tabular}{|c|c|c|c|c|c|c|c|c|c|c|c|}
\hline Specimen & $\begin{array}{l}\mathrm{SiO}_{2} \\
(\%)\end{array}$ & $\begin{array}{c}\mathrm{Al}_{2} \mathrm{O}_{3} \\
(\%)\end{array}$ & $\mid \begin{array}{c}\mathrm{Fe}_{2} \mathrm{O}_{3} \\
(\%)\end{array}$ & $\begin{array}{c}\mathrm{MgO} \\
(\%)\end{array}$ & $\begin{array}{l}\mathrm{CaO} \\
(\%)\end{array}$ & $\begin{array}{c}\mathrm{Na}_{2} \mathrm{O} \\
(\%)\end{array}$ & $\begin{array}{l}\mathrm{K}_{2} \mathrm{O} \\
(\%)\end{array}$ & $\begin{array}{l}\mathrm{P}_{2} \mathrm{O}_{5} \\
(\%)\end{array}$ & $\mathrm{H}_{2} \mathrm{O}$ & Total & $\begin{array}{l}\text { Corresponding } \\
\text { mineral }\end{array}$ \\
\hline $504^{1}$ & 98.2 & - & - & - & - & - & - & - & - & 98.2 & quartz \\
\hline $504^{2}$ & 99.4 & - & - & - & - & - & - & - & - & 99.4 & quartz \\
\hline $508^{1}$ & 98.4 & - & - & - & - & - & - & - & - & 98.4 & quartz \\
\hline $508^{2}$ & 98.0 & - & - & - & - & - & - & - & - & 98.0 & quartz \\
\hline $510^{1}$ & 99.0 & - & - & - & - & - & - & - & - & 99.0 & quartz \\
\hline $510^{2}$ & 98.9 & - & - & - & - & - & - & - & - & 98.9 & quartz \\
\hline $516^{1}$ & 99.9 & - & - & - & - & - & - & - & - & 99.9 & quartz \\
\hline $516^{2}$ & 98.7 & - & - & - & - & - & - & - & - & 98.7 & quartz \\
\hline $517^{1}$ & 98.5 & - & - & - & - & - & - & - & - & 98.5 & quartz \\
\hline $517^{2}$ & 98.3 & - & - & - & - & - & - & - & - & 98.3 & quartz \\
\hline $526^{1}$ & 98.3 & - & - & - & - & - & - & - & - & 98.3 & quartz \\
\hline $526^{2}$ & 98.9 & - & - & - & - & - & - & - & - & 98.9 & quartz \\
\hline $527^{1}$ & 98.9 & - & - & - & - & - & - & - & - & 98.9 & quartz \\
\hline $527^{2}$ & 98.3 & - & - & - & - & - & - & - & - & 98.3 & quartz \\
\hline $505^{1}$ & 59.0 & 0.8 & 0.5 & 25.0 & 12.5 & - & - & - & 2.12 & 99.9 & tremolite \\
\hline $505^{2}$ & 58.2 & 1.1 & 0.5 & 24.8 & 13.1 & - & - & - & 2.12 & 99.8 & tremolite \\
\hline $506^{1}$ & 58.6 & 0.7 & 0.5 & 24.5 & 13.5 & - & - & - & 2.12 & 99.9 & tremolite \\
\hline $506^{2}$ & 58.3 & 0.7 & 0.5 & 24.4 & 13.9 & - & - & - & 2.12 & 99.9 & tremolite \\
\hline $520^{1}$ & 58.5 & 0.7 & 0.6 & 24.2 & 13.8 & - & - & - & 2.12 & 99.9 & tremolite \\
\hline $520^{2}$ & 58.4 & 0.9 & 0.8 & 23.7 & 13.9 & - & - & - & 2.12 & 99.8 & tremolite \\
\hline tremolite $^{(2)}$ & 58.54 & 0.79 & 0.22 & 24.45 & 13.58 & 0.27 & 0.12 & - & 2.12 & 100.0 & - \\
\hline $507^{1}$ & 48.7 & 31.1 & - & - & 18.8 & 1.6 & - & - & - & 100.2 & anorthite \\
\hline $507^{2}$ & 47.4 & 32.0 & - & - & 18.9 & 1.6 & - & - & - & 99.9 & anorthite \\
\hline anorthite $^{(1)}$ & 44.40 & 35.84 & - & - & 19.20 & 0.56 & - & - & - & 100.0 & - \\
\hline $509^{1}$ & \begin{tabular}{|l|}
- \\
\end{tabular} & 21.6 & 12.7 & - & - & - & - & 45.3 & 21.0 & 100.6 & variscite-strengite \\
\hline $509^{2}$ & - & 30.1 & 3.2 & - & - & - & - & 46.2 & 21.0 & 100.5 & variscite-strengite \\
\hline variscite $^{(1)}$ & - & 32.27 & - & - & - & - & - & 44.92 & 22.81 & 100.0 & - \\
\hline strengite $^{(1)}$ & - & - & 42.73 & - & - & - & - & 37.98 & 19.28 & 100.0 & - \\
\hline $512^{1}$ & 66.7 & 18.2 & \begin{tabular}{|l|}
- \\
\end{tabular} & - & - & - & 14.1 & - & - & 99.0 & microcline \\
\hline $512^{2}$ & 65.7 & 20.7 & - & - & - & 11.7 & - & - & - & 98.1 & albite \\
\hline $513^{1}$ & 71.5 & 20.0 & - & - & - & 10.0 & - & - & - & 101.7 & albite \\
\hline $513^{2}$ & 65.8 & 18.0 & - & - & - & - & 14.4 & - & - & 98.2 & microcline \\
\hline $514^{1}$ & 68.2 & 18.9 & - & - & - & 11.0 & - & - & - & 98.1 & albite \\
\hline $514^{2}$ & 68.8 & 16.1 & - & - & - & - & 15.0 & - & - & 99.9 & microcline \\
\hline $515^{1}$ & 67.2 & 18.3 & - & - & - & - & 13.3 & - & - & 98.8 & microcline \\
\hline $515^{2}$ & 68.3 & 18.7 & - & - & - & 11.1 & - & - & - & 98.1 & albite \\
\hline $521^{1}$ & 68.8 & 14.1 & - & - & - & 0.9 & 15.7 & - & - & 99.5 & microcline \\
\hline $521^{2}$ & 67.9 & 19.5 & - & - & - & 12.1 & - & - & - & 99.5 & albite \\
\hline $522^{1}$ & 67.1 & 19.9 & - & - & 0.1 & 11.3 & - & - & - & 98.4 & albite \\
\hline $522^{2}$ & 64.5 & 19.7 & - & - & - & 1.2 & 15.1 & - & - & 100.5 & microcline \\
\hline $523^{1}$ & 64.8 & 19.2 & - & - & - & - & 16,9 & - & - & 100.9 & microcline \\
\hline $523^{2}$ & 67.2 & 19.9 & - & - & - & 12.0 & - & - & - & 99.1 & albite \\
\hline albite $^{(1)}$ & 67.39 & 20.35 & - & - & 1.07 & 11.19 & - & - & - & 100.0 & - \\
\hline microcline $^{(1)}$ & 64.76 & 18.32 & - & - & - & - & 16.92 & - & - & 100.0 & - \\
\hline $518^{1}$ & \begin{tabular}{|l|}
59.1 \\
\end{tabular} & \begin{tabular}{|l|}
23.4 \\
\end{tabular} & 0.2 & - & - & 15.5 & \begin{tabular}{|l|}
- \\
\end{tabular} & - & - & 98.2 & jadeite \\
\hline $518^{2}$ & 58.6 & 24.3 & 0.2 & - & - & 15.1 & - & - & - & 98.2 & jadeite \\
\hline $519^{1}$ & 58.7 & 24.3 & 0.1 & - & - & 16.5 & - & - & - & 99.6 & jadeite \\
\hline $519^{2}$ & 59.1 & 24.5 & 0.1 & - & - & 14.8 & - & - & - & 98.5 & jadeite \\
\hline $524^{1}$ & 67.1 & 20.3 & 0.2 & - & - & 11.8 & - & - & - & 99,4 & jadeite \\
\hline $524^{2}$ & 66.2 & 20.0 & 0.1 & - & - & 13.1 & - & - & - & 99.4 & jadeite \\
\hline $525^{1}$ & 60.5 & 24.7 & 0.2 & - & - & 13.3 & - & - & - & 98.7 & jadeite \\
\hline $525^{2}$ & 59.5 & 21.0 & 3.3 & - & - & 14.3 & - & - & - & 98.1 & jadeite \\
\hline jadeite ${ }^{(1)}$ & 58.61 & 22.38 & 3.89 & - & - & 15.11 & - & - & - & 100.0 & - \\
\hline
\end{tabular}

quitãs 505,506 , and 520 is dominated by almost pure tremolite, with low levels of iron oxide $(0.5 \%, 0.6 \%$, and $0.8 \%$, respectively), reinforcing the mineralogical

Table 1

Chemical composition of the muiraquitãs analyzed in the present study by SEM/ EDS. For specimens 505, 506, 507, and 520 , which are made of tremolite, $\mathrm{H}_{2} \mathrm{O}$ (LOI) was considered to be 2.12 weight $\%$, whereas for specimen 509 (made of variscite-strengite, based on their respective chemical compositions), $\mathrm{H}_{2} \mathrm{O}$ (LOI) was considered to be 21 weight \%. 
diagnosis provided by XRD. The minimal variation in the chemical composition of these muiraquitãs, especially in the principal components $\mathrm{SiO}_{2}, \mathrm{MgO}$, and $\mathrm{CaO}$, suggests that they were derived from the same source rock or site.

The chemical composition of muiraquitã 509 , with $21.6 \%$ and $30.1 \% \mathrm{Al}_{2} \mathrm{O}_{3}$, $3.7 \%$ and $12.7 \% \mathrm{Fe}_{2} \mathrm{O}_{3}$, and $45.3 \%$ and $46.2 \% \mathrm{P}_{2} \mathrm{O}_{5}$, supports the conclusion that the phosphate is in fact the isomorphic variscite-strengite series, and not pure variscite, as identified by XRD, re-emphasizing the importance of the SEM/EDS chemical analyses for the identification of the mineral. The chemical

Table 2

Comparison of the chemical composition of the jadeite muiraquitãs analyzed in the present study using SEM/EDS, and jadeite from Montagua, Guatemala.

\section{Conclusions}

The muiraquitãs analyzed in the present study are made from a variety of different geological materials, as shown by their mineralogical and chemical composition. This conclusion contradicts the idea that these pieces are all made of jadeite derived from a common source, often thought to be Asiatic in origin.

Of the 23 pieces examined here, seven are made of quartz, seven of albite, microcline, and quartz, three of tremolite, which is also known as nephritic jade, one is made of variscite-strengite, one of anorthite and four of jadeite. These minerals are all relatively common components of igneous and metamorphic rocks, which are found in outcrops throughout most of the Amazon basin. Obviously, therefore the origin of these pieces may be local.

Considering all the specimens analyzed up to the present time, including those from the collections of the Museu Goeldi (Goeldi Museum) and the Museu de Arqueologia e Etnografia (Museum of Archeology and Ethnology) of the Universidade de São Paulo (USP) (University of São Paulo), only those of one museum - the Museu do Encontro - included analyses of specimens $512,513,514,515$, 521,522 , and 523 returned levels of $\mathrm{SiO}_{2}$, $\mathrm{Al}_{2} \mathrm{O}_{3}, \mathrm{Na}_{2} \mathrm{O}$, and $\mathrm{K}_{2} \mathrm{O}$ compatible with the mineralogical diagnosis provided by $\mathrm{X}$-ray diffraction, i.e. albite + microcline + quartz. At least some of these pieces may also have been extracted from the same rock matrix, or the same geological region, derived from rock with a granitic or pegmatitic-granitic composition, which is common in the archean and proterozoic geological terrains of the Amazon region, which outcrop in many areas, in both and river valleys and beds. The chemical composition of specimen 507 confirms the presence of anorthite (as identified by XRD), a rare mineral found in rocks such as anorthosites, which are found in the Amazon basin, as well as in skarns. Anorthite and variscite-strengite, beside jadeite, are the rarest minerals found in the muiraquitãs analyzed to date.

The chemical composition of specimens 518, 519, 524, and 525 from the Museu do Encontro, identified as pure jadeite by X-ray diffraction, was typical of this mineral. Their levels of $\mathrm{SiO}_{2}$ (58.6$67.1 \%), \mathrm{Al}_{2} \mathrm{O}_{3}(20-24.7 \%)$, and $\mathrm{Na}_{2} \mathrm{O}$ $(8.8-15.5 \%)$ were equivalent to those of jadeite from Montagua, Guatemala (Rochette, 2007; Hernandez, 2000; Feldman, 1975), as shown in Table 2.

\begin{tabular}{|c|c|c|c|c|c|c|c|c|}
\hline Samples & $\begin{array}{l}\mathrm{SiO}_{2} \\
(\%)\end{array}$ & $\begin{array}{c}\mathrm{Al}_{2} \mathrm{O}_{3} \\
(\%)\end{array}$ & $\begin{array}{c}\mathrm{Fe}_{2} \mathrm{O}_{3} \\
(\%)\end{array}$ & $\begin{array}{c}\mathrm{MgO} \\
(\%)\end{array}$ & $\begin{array}{l}\mathrm{CaO} \\
(\%)\end{array}$ & $\begin{array}{c}\mathrm{Na}_{2} \mathrm{O} \\
(\%)\end{array}$ & $\begin{array}{l}\mathrm{K}_{2} \mathrm{O} \\
(\%)\end{array}$ & $\begin{array}{l}\mathrm{P}_{2} \mathrm{O}_{5} \\
(\%)\end{array}$ \\
\hline $518^{1}$ & 59.1 & 23.4 & 0.2 & - & - & 15.5 & - & - \\
\hline $518^{2}$ & 58.6 & 24.3 & 0.2 & - & - & 15.1 & - & - \\
\hline $519^{1}$ & 58.7 & 24.3 & 0.1 & - & - & 16.5 & - & - \\
\hline $519^{2}$ & 59.1 & 24.5 & 0.1 & - & - & 14.8 & - & - \\
\hline $524^{1}$ & 67.1 & 20.3 & 0.2 & - & - & 11.8 & - & - \\
\hline $524^{2}$ & 66.2 & 20.0 & 0.1 & - & - & 13.1 & - & - \\
\hline $525^{1}$ & 60.5 & 24.7 & 0.2 & - & - & 13.3 & - & - \\
\hline $525^{2}$ & 59.5 & 21.0 & 3.3 & - & - & 14.3 & - & - \\
\hline \begin{tabular}{c|} 
average \\
\end{tabular} & 59.1 & 23.4 & 0.2 & - & - & 15.5 & - & - \\
\hline Guatemalan jadeite $^{(3)}$ & 59.2 & 23.7 & 0.3 & - & 1.1 & 14.4 & - & - \\
\hline
\end{tabular}

pieces made from the most intriguing mineral of all, jadeite. This mineral was identified in four specimens $(518,519$, 524 , and 525). Jadeite is still unknown from the geological outcrops or subsoil of the Brazilian Amazon basin, or any other part of the country. The identification of this mineral from the pieces in the Museu do Encontro collection would appear to reopen the discussion with regard to the geographic and geological origins of the muiraquitãs found in the Amazon. Prior to the present study, muiraquitãs were generally thought to be Amazonian in origin, given that no jadeite pieces (only nephritic jade) had been identified in the collections. Rocks rich in tremolite and tremolite-actinolite are common in many of the region's geological environments, where they are found in both ultramafic and metamorphic terrains.

One possibility is that the jadeite found in the muiraquitãs from the collection of the Museu do Encontro originated from Central America, given the presence of this mineral in a large area adjacent to the Montagua River in Guatemala. This is the closest site with archeological affini- ties with the Amazon region. However, the chemical composition of the jadeite in these pieces is slightly different from that of Montagua with regard to the levels of $\mathrm{Na}_{2} \mathrm{O}$ and $\mathrm{CaO}$. Further studies, in particular using trace elements, would throw additional light onto the geochemical affinities of these materials, and would help to determine whether the muiraquitãs were made from Guatemalan jadeite. Additional research is needed in order to define the true origin of this mineral, and thus of the muiraquitãs themselves, and in particular, their authenticity.

If the Central American origin is confirmed, an extensive commercial route may have existed, linking a diversity of societies, including those in the Amazon basin. This would obviously contradict the idea that the artifacts originated in Asia. Batrachian artifacts similar to the muiraquitãs of the Amazon basin have been found on a number of Caribbean islands (Boomert, 1987), sculpted from a variety of rocks and minerals, but rarely jade, and also in the Guyanas (Rochette, 2007; Hernandez, 2000; Feldman, 1975). 


\section{Acknowledgments}

We thank the PRONEX-MINOMAT Project (FADESPA-FADESP-UFPA-CNPQ consortium). The second author is grateful to $\mathrm{CNPq}$ for covering laboratory costs and granting concession. We are also grateful to the Pará state government, through its Culture ministry, which granted access to the valuable collections of muiraquitãs deposited in the Gemstone and Meeting museums. We thank Dr. Hilton Tulio Costi of the Museu Goeldi (Goeldi Museum), for conducting the SEM/EDS analyses.

\section{References}

BARATA, F. O muiraquitã e as contas dos Tapajós. Revista do Museu Paulista, v.8, p. 229-252, 1954.

BOOMERT, A. Gifts of the amazons; "green stone" pendants and beads as items of ceremonial exchange in Amazonia and the Caribbean. Antropologica, v.67, p.3354, 1987.

COSTA, M. L., SIlVA, A. C. R. L., ANGÉliCA, R. S., PÖllmanN, H., SCHUKAMNN, W. Muyrakytã ou muiraquitã: um talismã arqueológico em jade procedente da Amazônia: aspectos físicos, mineralogia, composição química e sua importância etnográfico-geológica. Acta Amazônica, v. 32, n. 3, p. 431-448, 2002a.

COSTA, M. L., SILVA, A. C. R. L., ANGÉLICA, R. S. Muyrakytã ou Muiraquitã: um talismã arqueológico em jade procedente da Amazônia: uma revisão histórica e considerações antropogeológicas. Acta Amazônica, v. 32, n. 3, p. 467-490, 2002 b.

DEER, W. A., HOWIE, R. A., ZUSSMAN, J.(eds.). An introduction to the rockforming minerals. England: Longman Scientific \& Technical, 1993 . 69p.

FELDMAN, L. H., TERZUOLA, R., SHEETS, P., CAMERON, C. (eds.). Jade workers in the Montagua valley. Columbia: University of Missouri, 1975. p.1-15.

FISCHER, H. Ueber nephritbeile aus Brasilien und Venezuela. Geologie und Paleontologie. p. 214-217, 1884.

HERNÁNDEZ, B. A. A. Los yacimientos de jade en el valle del Montagua, Guatemala. Revista de Arqueologia de México, p.1-7, 2000.

KOEHLER, A, I. O problema do muiraquitã. Revista do Museu Paulista, v.5, p. 199220, 1951.

MINERALOGY DATABASE http://webmineral.com. Access 05/04/2011.

MCBIRNEY, A. Eclogites and jadeite from the Montagua fault zone, Guatemala. The American Mineralogist, v.52, p. 908-918, 1967.

MORAES, L. J. Sobre o jade no Brasil. Anais da Academia Brasileira de Ciências, v.4, n. 2, p. 63-66, 1932.

RODRIGUES, B. O Muyrakytã e os ídolos simbólicos. Rio de Janeiro: Imprensa Nacional, 1899. 210p.

ROCHETTE, E. T. Investigación sobre producción de gienes de prestigio de jade en el valle medio del Montagua, Guatemala. Revista de Arqueologia de México, p.1-35, 2007.

SILVA, A. C. R. L., COSTA, M. L., ANGÉLICA, R. S. O muiraquitã (muirakytã). REM - Revista Escola de Minas, v. 51, n. 2, p. 24-29, 1997.

Artigo recebido em 25 de maio de 2011. Aprovado em 29 de setembro de 2011. 